\title{
Ilustrasi yang Berbentuk Cerita sebagai Salah Satu Unsur Penting dalam Khotbah
}

\author{
Hari Soegianto* \\ *Penulis adalah dosen penuh waktu di Sekolah Tinggi Teologi SAAT Malang \\ dan mengajar mata kuliah Homiletika dan Pendidikan Kristen. \\ Email: hari.soegianto@seabs.ac.id
}

\begin{abstract}
Abstrak: Ilustrasi sebagai unsur sebuah khotbah selama ini dikenal memiliki peran untuk memperjelas sebuah ide, menarik perhatian pendengar, bahkan juga dapat menggerakkan emosi pendengar. Sekalipun berdasarkan definisinya ilustrasi dapat memiliki berbagai bentuk, tetapi tidak semua bentuk itu memberikan pengaruh yang sama. Ilustrasi yang berbentuk cerita memiliki keunggulan dibandingkan dengan bentuk-bentuk yang lain. Tulisan ini menggali keunggulan dari ilustrasi yang berbentuk cerita berdasarkan studi yang pernah dilakukan berkaitan dengan bagaimana sebuah informasi dapat dengan lebih mudah dipahami oleh penerimanya. Berdasarkan pemahaman tentang cara kerja otak manusia, bagaimana manusia berkomunikasi, bagaimana manusia belajar, bahkan pengamatan dalam khotbah sendiri, menunjukkan bahwa ilustrasi yang berbentuk cerita dapat menjadi alat yang efektif dalam penyampaian sebuah kebenaran.
\end{abstract}

Kata-kata kunci: Khotbah, Ilustrasi, Ilustrasi yang Berbentuk Cerita, Otak Manusia, Komunikasi, Teori Belajar, Generals, Particulars

\begin{abstract}
An illustration as an element of a sermon has been known to play a role in clarifying an idea, attracting the attention of listeners, and to even move the emotions of the listeners. Even though, by definition, illustrations can take various forms, not all of them have the same effect. Illustrations in the form of stories have certain advantages compared to other forms of illustrations. This paper explores the advantages of illustrations in the form of stories based on studies that have been conducted in relation to how information can be more easily understood by recipients. Based upon an understanding of how the human brain works, how humans communicate, how humans learn, and even observations about the sermon being preached, shows that illustrations in the form of stories can be effective tools for conveying a truth.
\end{abstract}

Keywords: Sermon, Illustration, A Story Illustration, Human Brain, Communication, Study Theory, Generals, Particulars 


\section{Pendahuluan}

Ilustrasi merupakan salah satu topik yang banyak mendapat perhatian dari para ahli homiletika. Al Fasol menjelaskan bahwa ilustrasi berperan untuk menolong pendengar memahami penjelasan dan aplikasi dalam khotbah dengan lebih baik. Ia menyatakan, "Its verb form, 'illustrate,' comes from the Latin 'illustrare,' which means 'to cast light upon.' A sermon illustration has a specific, narrowly assigned, and limited role: to cast light on one or more facets of an explanation or application." Charles H. Spurgeon menggambarkan ilustrasi dalam sebuah khotbah itu seperti jendela pada sebuah rumah. Sebagaimana jendela pada sebuah rumah dibuat untuk menerangi rumah itu, demikian pula ilustrasi diperlukan dalam sebuah khotbah untuk menerangi atau membuat jelas. Ia menyatakan, "Parables, similes, and metaphors have that effect; and hence we use them to illustrate our subject, or, in other words, to 'brighten it with light." ${ }^{2}$ Haddon W. Robinson melukiskan hal ini dengan lebih jelas. Ia menyatakan bahwa sebuah ilustrasi itu seperti gambar di televisi, di mana gambar itu membuat jelas apa yang dikatakan oleh pembicaranya. ${ }^{3}$ Lebih dari itu, Robinson juga melihat ilustrasi sebagai sebuah unsur yang penting untuk "mendaratkan" khotbah itu dalam kehidupan pendengar. Ia menyatakan, "One means of earthing our sermons lies in the use of illustrations." ${ }^{4}$ Mengapa bisa terjadi seperti itu? John R.W. Stott menjelaskan bahwa ilustrasi merupakan alat yang bisa digunakan untuk merangsang imajinasi pendengar dan menolong mereka untuk melihat sesuatu dengan lebih jelas dalam pikiran mereka. Ia menyatakan, "Illustrations transform the abstract into the concrete, the ancient

${ }^{1} \mathrm{Al}$ Fasol, Essentials for Biblical Preaching: An Introduction to Basic Sermon Preparation (Grand Rapids: Baker, 1989), 82.

${ }^{2}$ Charles H. Spurgeon, "Illustration in Preaching," dalam The Company of Preachers, ed. Richard Lischer (Grand Rapids: Eerdmans, 2002), 317.

${ }^{3}$ Haddon W. Robinson, Biblical Preaching (Grand Rapids: Baker, 1980), 149.

${ }^{4}$ Ibid. into the modern, the unfamiliar into the familiar, the general into the particular, the vague into the precise, the unreal into the real, and the invisible into the visible." 5 Dengan demikian dapat disimpulkan bahwa ilustrasi merupakan salah satu unsur yang penting dalam sebuah khotbah. Ia berperan untuk menjelaskan suatu ide atau konsep melalui bentuk perbandingan atau penggambaran terhadap ide atau konsep tersebut, sehingga para pendengar dapat memahami ide atau konsep itu dengan lebih baik. Harold T. Bryson menyatakan, "If an expositor cannot produce an analogy, the hearer may not understand the point. Illustrations furnish listeners with examples of abstract truth."

Namun, di samping itu ada pula beberapa fungsi lain dari ilustrasi yang berkaitan dengan keberadaannya dalam sebuah khotbah. Gambaran ilustrasi seperti jendela pada sebuah rumah yang dilukiskan oleh Spurgeon menunjukkan bahwa ilustrasi dapat membuat sebuah khotbah menjadi menyenangkan dan menarik, seperti sebuah jendela yang membuat sebuah rumah menjadi lebih menyenangkan dan tidak seperti sebuah penjara yang terkesan gelap dan tidak menarik. Ilustrasi juga membangkitkan para pendengar dan menarik perhatian mereka, seperti embusan angin yang mengalir dari jendela rumah dan memberikan kesegaran. ${ }^{7}$ Bukankah itu yang kita rasakan ketika mendengarkan ilustrasi dalam sebuah khotbah? Bahkan, jika kita berada pada posisi pengkhotbah, kita akan melihat kepala-kepala yang kembali terangkat setelah menunduk sekian lama. Sebuah ilustrasi akan menarik perhatian pendengar dan menyegarkan mereka kembali untuk mendengarkan lebih lanjut. Bryson menyatakan, "Listeners long for diversity and interesting matters. Humor, a life experience, or some other

${ }^{5}$ John R.W. Stott, Between Two Worlds: The Challenge of Preaching Today (Grand Rapids: Eerdmans, 1982), 239.

${ }^{6}$ Harold T. Bryson, Expository Preaching: The Art of Preaching through a Book of the Bible (Nashville: Broadman \& Holman, 1995), 392.

${ }^{7}$ Spurgeon, "Illustration in Preaching," 317-319. 
type of illustration has the power to sustain or to reclaim an audience's interest."

Selain itu, Robinson menjelaskan bahwa sebuah ilustrasi dapat menolong pendengar untuk mengingat, menggerakkan emosi, menciptakan kebutuhan, menarik perhatian dan menghubungkan pengkhotbah dengan para pendengarnya. ${ }^{9}$ Ia juga menunjukkan bahwa ilustrasi berperan untuk membuat kebenaran yang disampaikan dapat diyakini oleh para pendengar. Menurutnya, memang secara logika, contoh-contoh itu tidak dapat berdiri sebagai bukti, tetapi secara psikologis halhal itu bekerja sama dengan argumen yang diberikan untuk mendapatkan penerimaan dari mereka yang mendengarnya. ${ }^{10}$ Sisi emosional yang disentuh melalui ilustrasi membuat kebenaran itu menjadi lebih mudah diterima oleh seseorang. Carter, Duvall dan Hays menyatakan, "Illustrations are capable of infusing the sermon with an emotional charge that connects the message, the audience, and their culture."11 Kekuatan yang dimiliki oleh sebuah ilustrasi mampu menghancurkan "benteng-benteng pertahanan" yang dimiliki oleh para pendengar. Bryson menjelaskan, "Making a direct attack against what an expositor exposes and opposes might make hearers defensive. But an appropriate illustration can penetrate human defense as did Nathan's story to David." 12 Bryan Chapell juga menunjukkan bahwa ilustrasi dapat menjangkau hati dan menjangkau kehendak. Kemampuan ilustrasi menggerakkan emosi pendengar membuat ia tidak hanya "mendaratkan" informasi dalam pikiran para pendengar, tetapi juga mampu menggerakkan respons untuk membuat keputusan, sehingga dapat memengaruhi kehendak para pendengarnya. Ia menyatakan, "We do not make decisions solely on the basis of

\footnotetext{
${ }^{8}$ Bryson, Expository Preaching, 392.

${ }^{9}$ Robinson, Biblical Preaching, 150.

${ }^{10}$ Ibid., 149-150.

${ }^{11}$ Terry G. Carter, J. Scott Duval, dan J. Daniel Hays, Preaching God's Word (Grand Rapids: Zondervan, 2005), 136.
}

${ }^{12}$ Bryson, Expository Preaching, 393. what we know. We also decide because of how we feel about what we know. Illustrations recognize and employ this dynamic." 13

Pada aspek yang lain, Robinson juga menunjukkan bahwa ilustrasi berperan untuk membawa ide-ide kepada pengalaman. Contoh-contoh yang diberikan menunjukkan bagaimana kebenaran itu dinyatakan dalam tindakan. ${ }^{14}$ John Kilinger menjelaskan, "Sebuah khotbah yang baik biasanya mencapai keseimbangan yang sehat antara abstraksi dan penggambaran." 15 Ilustrasi akan menjadi penyeimbang agar khotbah itu tidak hanya berupa lontaran ide pengkhotbah. Kilinger mendasari pendapatnya dari penelitian modern tentang otak, di mana otak manusia memiliki belahan kanan dan belahan kiri. Yang satu mengontrol bagian yang bersifat meditatif dan imajinatif, sedangkan yang lain mengontrol bagian yang bersifat pragmatis dan analitis. Ilustrasi merupakan unsur khotbah yang banyak memberikan rangsangan pada belahan otak kanan, di mana pola penerimaannya lebih bersifat penggambaran. ${ }^{16}$

Banyaknya fungsi ilustrasi tidak berarti bahwa ilustrasi adalah segala-galanya dalam sebuah khotbah. Dengan menggunakan gambaran jendela pada sebuah rumah, Spurgeon menyatakan, "But a house is not erected for the sake of the windows, nor may a sermon be arranged with the view fitting in a favorite apologue. A window is merely a convenience subordinate to the entire design, and so the best illustration."17 Demikian juga Bryson menjelaskan:

Expository preaching should be concerned with exposing biblical truth and meeting human needs. As long as illustrations illumine truth, they should be present as content material. But when an illustration becomes

\footnotetext{
${ }^{13}$ Bryan Chapell, Using Ilustrations to Preach with Power (Wheaton: Crossway, 2001), 37-39.

${ }^{14}$ Robinson, Biblical Preaching, 149-150.

${ }^{15}$ John Kilinger, Dasar-dasar Khotbah (Jakarta: Gunung Mulia, 2011), 122.

${ }^{16}$ Ibid., 121-122.

${ }^{17}$ Spurgeon, "Illustration in Preaching," 320.
} 
the end rather than the means, they should be eliminated. ${ }^{18}$

Kesadaran tentang hal ini merupakan hal yang penting, supaya para pengkhotbah dapat bersikap dengan tepat, tidak ekstrem pada salah satu sisi, khususnya dalam kaitan dengan keberadaan ilustrasi dalam sebuah khotbah. Ilustrasi harus dipandang sebagai unsur yang penting dalam sebuah khotbah, tetapi ia hanya unsur yang akan membuat jelas kebenaran Alkitab yang disampaikan dalam khotbah itu. Ia tidak boleh mendistorsi kebenaran sehingga membuat para pendengar salah memahami berita yang disampaikan. Hanya dengan cara demikian peran ilustrasi yang bagaikan jendela pada sebuah rumah berada pada tempat yang tepat. William Torgesen III menyatakan, "Illustrations are just a tool to aid in the communication of God's Word and must never serve as a replacement for the truth." 19

\section{Jenis-jenis Ilustrasi}

Menurut Bryson, ada tiga jenis utama ilustrasi, yaitu keterampilan penggunaan bahasa, penggunaan cerita, penggunaan puisi dan kutipan. Hal-hal yang termasuk kategori ini adalah frasa (berupa ungkapan umum atau bentuk perbandingan sederhana), kalimat (berupa kalimat yang disusun dengan baik sehingga mudah diingat), cerita (berupa alegori, fabel, perumpamaan, pengalaman hidup, anekdot, drama, dan kejadian-kejadian historis), puisi dan kutipan (berupa sajak atau himne, kalimat bijak atau amsal), humor (baik berupa penggunaan bahasa, cerita, puisi atau kutipan, yang membangkitkan rasa lucu). ${ }^{20}$ John Kilinger mendaftar cakupan bahan-bahan yang bersifat ilustrasi, yaitu ilustrasi-ilustrasi Alkitab, historis, biografis, humor, ilmiah, geografis atau topografis, puitis atau retoris, fiksional, olahraga, artistik atau musikal, teatrikal, kebudayaan lain (iklan, karya nonfiksi populer, tinjauan buku, acara komedi, dan

\footnotetext{
${ }^{18}$ Bryson, Expository Preaching, 391.

${ }^{19}$ William Torgesen III, "Learning to Tell the Story," dalam The Moody Handbook of Preaching, ed. John Koessler (Chicago: Moody, 2008), 270.
}

${ }^{20}$ Lih. Bryson, Expository Preaching, 394-396. acara televisi), surat, dan ilustrasi-ilustrasi pribadi. ${ }^{21}$ Seorang pengkhotbah dapat menggunakan berbagai bentuk tersebut agar khotbahnya dapat menarik, mudah dimengerti, mudah diingat, dan menggerakkan hati pendengar untuk melakukannya. Namun, secara khusus, ilustrasi yang berbentuk cerita memiliki keunggulan dibandingkan dengan bentuk-bentuk yang lain. Sekalipun berdasarkan definisinya ilustrasi dapat memiliki berbagai bentuk, tidak semua bentuk itu memberikan pengaruh yang sama. Chapell menyatakan:

Figures, analogies, and examples can add rich expression to a sermon, but they do not involve listeners to the same degree as do true illustrations. A quote from an ancient saint or a statistic from a contemporary newspaper may add interest to a sermon, but neither carries the listener into tangible understanding of a message as effectively as a full illustration. ${ }^{22}$

Istilah "full illustration," yang disebut juga "true illustration" dalam hal ini adalah ilustrasi yang berbentuk cerita, seperti perumpamaan, alegori, atau cerita-cerita pendek. Chapell menjelaskan bahwa melalui detail-detail sebuah cerita, para pendengar dapat membayangkan masuk dalam suatu pengalaman di mana kebenaran dari khotbah itu dapat diamati. Pengkhotbah menceritakan tentang apa, kapan, di mana, dan mengapa dari sebuah peristiwa untuk menolong para pendengar memiliki akses masuk pada pemahaman tentang kebenaran itu. Melalui cerita itu para pendengar didorong untuk melihat, merasa, mengecap, dan menghirup bagian-bagian dari sebuah peristiwa, seolah-olah mereka secara fisik hadir dalam kisah yang disampaikan. Pada prinsipnya, di dalam sebuah ilustrasi, pengkhotbah mengundang para pendengar untuk masuk ke dalam pengalaman. ${ }^{23}$ Karena itu secara lebih khusus, Chapell menjelaskan, "Illustrations are 'life-situation' stories within

\footnotetext{
${ }^{21}$ Kilinger, Dasar-dasar Khotbah (Jakarta: Gunung Mulia, 2011), 128-139.

${ }^{22}$ Chapell, Using Illustrations, 21.

${ }^{23}$ Ibid.
} 
sermons whose details (whether explicitly told or imaginatively elicited) allow listeners to identify with an experience that elaborates, develops, and explains scriptural principles." 24

\section{Keunggulan Ilustrasi yang Berbentuk Cerita}

Dari zaman ke zaman cerita-cerita mewarnai hidup manusia, baik yang bersifat pendidikan maupun hiburan. Apalagi dengan perkembangan teknologi saat ini, cerita-cerita tidak hanya ditemukan dalam toko-toko buku, tetapi juga dalam media elektronik dan komunikasi. Bahkan, setiap orang dapat berbagi cerita-cerita pribadi dan terhubung dengan sesama atau sebuah komunitas melalui media sosial, sehingga tidak terhitung lagi banyaknya cerita dalam dunia masa kini. Benarlah yang dikatakan oleh Fasol, "Telling a story is a timeless way to communicate." 25 Pertanyaannya, apakah keunggulan dari bentuk komunikasi ini, sehingga diminati orang dan bertahan sepanjang zaman?

\section{Pertama: Penelitian tentang Cara Kerja Otak Manusia Menunjukkan bahwa Cerita dapat Menjadi Alat Penghantar Pesan yang Efektif}

Jauh sebelum hal ini dijelaskan secara utuh, dalam Principles and Practice of Preaching (1956), Ilion T. Jones menyatakan, "Illustrations are essential because of the way the human mind functions." 26 Bryson menggunakan dasar teori yang sama untuk menjelaskan pentingnya penggunaan gambar dan cerita dalam sebuah khotbah. Ia menyatakan:

Early in the 1960s, scientists presented an interesting theory about the dual nature of the human brain. This theory, if true, would definitely affect the way a preacher shaped a sermon and added content. Scientists proposed the idea that each of the brain's two hemispheres-right and left-process

\section{${ }^{24}$ Ibid.}

${ }^{25}$ Fasol, Essentials for Biblical Preaching, 108.

${ }^{26}$ Sekalipun dalam hal ini Jones hanya bertujuan menjangkau orang-orang "biasa” yang tidak siap untuk berpikir (lih. Chapell, Using Illustrations, 24). information in different ways. According to this theory, the left hemisphere of the brain processes information analytically and verbally, dividing information into component parts. It understands and communicates truth by analyzing. The right hemisphere of the brain deals with information instinctually and visually. Scientists say the hemisphere are connected by the corpus callosum, allowing the two halves to interact. ${ }^{27}$

Ini menunjukkan bahwa manusia memiliki kemampuan untuk menciptakan gambargambar dan menggunakan logika narasi. Imajinasi yang dimiliki manusia itu mengubah fakta-fakta informasi dengan adegan-adegan kehidupan dan berbagai situasi untuk menghadirkan kebenaran yang tersembunyi. Imajinasi itu menciptakan gambaran-gambaran baru, sehingga para pendengar cerita dapat mengerti dan memahami kebenaran dalam bentuk yang baru. ${ }^{28}$ Masalahnya, menurut Bryson, selama ini banyak pengkhotbah telah dilatih homiletika tradisional, di mana mereka memproses dan mengomunikasikan informasi secara analitis (penjelasan, argumentasi, aplikasi). Hal ini menuntut perubahan dari para pengkhotbah di mana mereka tidak hanya mengembangkan otak kiri yang berkaitan dengan cara berpikir analitis, tetapi juga perlu mengembangkan otak kanan yang berkaitan dengan penggambaran, yaitu menggunakan ilustrasi. Ia menyimpulkan:

Preaching from a Bible book calls for the use of the whole brain in putting substance into sermons. Content from analytical reasoning and visual imagining could be used. Explanation, argumentation, and application come more from left brain reasoning. Illustration uses vision and imagination-both right brain functions. ${ }^{29}$

Dalam perkembangan lebih lanjut berkaitan dengan penelitian ini, ada di antara para ilmuwan yang cenderung tidak setuju dengan dikotomi antara belahan otak kiri dan

\footnotetext{
${ }^{27}$ Bryson, Expository Preaching, 397-398.

${ }^{28}$ Ibid., 398.

${ }^{29}$ Ibid.
} 
belahan otak kanan. ${ }^{30}$ Mereka berpendapat bahwa sekalipun dua belahan itu berfungsi secara berbeda, tetapi mustahil memisahkan fungsi-fungsi itu dalam otak yang normal dan sehat. Meskipun dua belahan otak itu memiliki keterampilan respons yang berbeda, tetapi mereka memahami, mempelajari, dan memproses dengan cara yang sama. Karena dua belahan itu tidak berfungsi secara sendiri-sendiri, maka mustahil untuk mendidik satu belahan otak saja pada otak yang normal. ${ }^{31}$ Namun, menurut penulis, hal ini tidak membuat pendapat Bryson menjadi lemah. Justru hal ini menunjukkan bahwa penggunaan gambar dan cerita dalam penyampaian informasi bukan saja sekadar untuk menyuplai kebutuhan otak kanan, tetapi merupakan sesuatu yang tidak dapat tidak, atau merupakan bagian yang penting dalam upaya tersampaikannya sebuah berita kepada pendengar.

\section{Kedua: Pemahaman tentang Bagaimana Manusia Berkomunikasi Menunjukkan bahwa Cerita merupakan Alat yang Efektif untuk Menyampaikan Sebuah Pesan}

Tujuan akhir dari sebuah komunikasi bukanlah komunikasi itu sendiri, tetapi komunikasi

\footnotetext{
${ }^{30}$ Alan Beaton setelah melakukan riset tentang lateralitas, menyimpulkan bahwa tidaklah tepat untuk mendeskripsikan fungsi belahan otak dalam istilah dikotomi apa pun (Left Side, Right Side: a Review of Laterality Research [New Haven: Yale University, 1985]). Jerre Levy, seorang peneliti fungsi otak kiri dan otak kanan, percaya bahwa walaupun adalah mungkin, dalam kondisi tertentu, untuk menunjukkan bahwa dua belahan itu berfungsi secara berbeda, adalah mustahil untuk memisahkan fungsi-fungsi itu dalam otak yang normal dan sehat ("Right Brain, Left Brain: Fact and Fiction," Psychology Today [May 1985], 38-39, 42-44). Penelitian terhadap perbedaan fungsi di kedua belahan otak ini terus dilanjutkan (Joseph B. Hellige, Hemispheric Asymmetry: What's Right and What's Left [Cambridge: Harvard University, 1993]; Alice Cronin-Golumb, "Semantic Network in the Divided Cerebral Hemispheres," Psychological Science 6 [1995], 212-218; Robert E. Ornstein, The Right Mind: Making Sense of the Hemisphere [New York: Harcourt Brace, 1997]), dan karya-karya yang lebih baru berkaitan belahan otak ini memberikan informasi yang berbeda dengan keyakinan umum tentang adanya dikotomi yang dianut pada 1970-an dan 1980-an (lih. B.R. Hergenhahn dan Matthew $\mathrm{H}$. Olson, Theories of Learning [Jakarta: Prenada Media, 2008], 419-420).
} 434.

${ }^{31}$ Hergenhahn dan Olson, Theories of Learning, 418- menjadi alat untuk mencapai tujuan, yaitu terjadinya pertemuan antara kebutuhan-kebutuhan manusia yang berkomunikasi tersebut. Oleh karena itu, Annette Simmons menyatakan bahwa para pendengar itu memerlukan lebih dari sekadar apa yang kita sampaikan. Mereka ingin merasakan kehadiran kita dalam berita yang kita sampaikan, sehingga mereka merasakan faktor "manusia" di dalamnya, di mana hal ini sering kali hilang dalam sebuah komunikasi. Menurut Simmons, cara untuk memasukkan unsur "manusia" dalam setiap komunikasi adalah dengan menyampaikan cerita-cerita. Melalui cerita-cerita itu pendengar akan merasa dipahami, terhubung dan tidak merasa sendiri. ${ }^{32}$

Sebuah cerita juga berfungsi sebagai penghantar dari ide-ide yang akan disampaikan. Berdasarkan pandangan para ahli komunikasi, Chappel menunjukkan bahwa cara terbaik menyampaikan ide-ide adalah dengan meletakkan ide-ide yang akan disampaikan itu dalam "human interest accounts, life-situations, life-stories, experience-centered messages, narrative-paradigms, firsthand encounter, piece of life illustrations, lived-body experience, and even a story that participates in the stories of those who have lived, who live now and who will live in the future." 33 Menurut Walter Fisher dalam Narration as a Human Communication Paradigm, cerita bukan sekadar salah satu alat komunikasi, tetapi ia adalah "master metaphor." 34 Inilah yang menyebabkan cerita juga menjadi alat yang efektif dalam sebuah khotbah. Cerita itu memiliki kekuatan untuk menyentuh hati, karena para pendengar dapat mengenali masalah-masalah, keadaan, atau emosi dari karakter utamanya, sehingga dapat terdorong untuk mengubah nilai-nilai mereka. John Koessler menyatakan, "Visual language and metaphor help to bridge the gap

${ }^{32}$ Annete Simmons, Whoever Tells the Best Story Wins: How to Use Your Own Stories to Communicate with Power and Impact (New York: American Management Association, 2007), 3-4.

${ }^{33}$ Chapell, Using Illustrations, 53.

${ }^{34}$ Ibid., 54. 
between cognition and motivation." 35 Glenn Nielsen menegaskan, "But the most important reason imagery has become so vital for preaching is that pictorial language engages the imagination and evokes response. Propositions appeal to the mind. Imagery appeals to the whole person-mind, emotions, and will." 36 Chapell menyimpulkan, "Narratives, especially as used in life-situation illustrations, enable us to know who we are, what others communicate, and what God communicates. They make it possible for us as preachers to bridge the gap between the pulpit and the pew." ${ }^{37}$ Ilustrasi yang berbentuk cerita menjadi sebuah alat yang membuat komunikasi yang terjadi antara pengkhotbah dan pendengar terjalin dengan baik.

\section{Ketiga: Pemahaman tentang Bagaimana Manusia Belajar Menunjukkan bahwa Cerita Menjadi Alat yang Efektif untuk Memahami Sebuah Ide yang Disampaikan}

Chapell menyatakan, "Listeners simply understand more when messages exhibit spiritual truths in stories of identifiable experiences." 38 Prinsip pembelajaran secara umum menunjukkan kebenaran ini. Pada awal 1950-an, Edgar Dale menyatakan bahwa belajar akan menjadi lebih efektif jika pembelajar bersentuhan langsung dan terlibat dalam proses itu. Pada tahun 1960-an, para guru didorong untuk menerapkan prinsip "learning pyramid," yang menunjukkan bahwa seseorang belajar 10 persen dari apa yang didengar, 30 persen dari apa yang dilihat, tetapi 60 persen dari apa yang dilakukan. Tahun 1970-an, para peneliti menemukan bahwa pengalaman yang diberikan kepada pembelajar merupakan sebuah cara yang efektif dalam belajar. Penyampaian cerita merupakan sebuah metode yang mampu membuat pendengar melihat,

${ }^{35}$ John Koessler, "View from the Pew," dalam The Art and Craft of Biblical Preaching, ed. Haddon Robinson dan Craig Brian Larson (Grand Rapids: Zondervan, 2005), 124-125.

${ }^{36}$ Glenn Nielsen, "Preaching Doctrine in a Postmodern Age," Concordia (January 2001), 25.

${ }^{37}$ Chapell, Using Illustrations, 54.

${ }^{38}$ Ibid., 53. merasakan dan ikut terlibat di dalam sebuah proses, sehingga melaluinya seseorang dapat memahami sebuah ide dengan baik. ${ }^{39}$

Di dalam perkembangan lebih lanjut tentang teori belajar, Albert Bandura mengemukakan teori kognitif sosial, di mana teori ini menekankan fakta bahwa seseorang memperoleh informasi dari interaksi orang tersebut dengan orang lain. Pengalaman seseorang dalam interaksi itu akan membuat ia belajar sesuatu, sehingga ia akan mengalami proses pembentukan perilaku, di mana hal-hal yang telah dipelajari itu diterjemahkan dalam tindakan. Namun, segala sesuatu yang dapat dipelajari dari pengalaman langsung juga bisa dipelajari melalui pengalaman tak langsung atau pengalaman pengganti, yaitu melalui observasi. Berdasarkan ini, proses pembelajaran dikembangkan dengan penggunaan model dalam belajar. Seseorang belajar dengan mengamati suatu model dalam memecahkan masalah dengan menggunakan cara tertentu. Melalui model itu ia mempelajari prinsip-prinsip yang dicontohkan, kemudian ia bertindak seperti model yang dilihatnya, bahkan mengembangkan perilaku itu dalam situasi dan kondisi yang berbeda. ${ }^{40}$ Sebuah cerita pada dasarnya dapat berperan seperti sebuah model dalam proses pembelajaran. Para pendengar mengamati apa yang sedang terjadi pada tokoh dari cerita itu, permasalahan apa yang timbul, dan bagaimana ia menyelesaikannya. Kebenarankebenaran yang dimunculkan melalui cerita itu akan diterima oleh pendengar, kemudian dibawanya ke dalam permasalahannya sendiri yang mungkin berbeda dengan yang diceritakan. Misalnya, seorang pengkhotbah mengajarkan bahwa pertolongan Tuhan itu nyata dalam hidup umat-Nya, dan ia menunjukkan dengan kisah bagaimana ia berharap kepada Tuhan dan kemudian Tuhan mencukupi kebutuhannya ketika istrinya melahirkan anak mereka yang kedua. Melalui cerita ini pendengar melihat sebuah model. Artinya, pendengar juga dapat berharap kepada pertolongan

\section{${ }^{39}$ Ibid.}

${ }^{40}$ Lih. B.R. Hergenhahn dan Matthew H. Olson, Theories of Learning (Jakarta: Prenada Media, 2008), 355-389. 
Tuhan. Mungkin pendengar tidak sedang berhadapan dengan masalah istri yang akan melahirkan, tetapi sekarang ia menempatkan kebenaran itu pada situasinya sendiri.

\section{Keempat: Penyampaian Cerita Memberi- kan Keseimbangan antara Generals (yang Umum) dan Particulars (yang Khusus) dalam Sebuah Khotbah}

Desain khotbah yang efektif harus memberikan keseimbangan antara bagian generals dan particulars. Ide atau amanat khotbah dan poin-poin khotbah termasuk generals, di mana bagian itu bersifat abstrak, konseptual, dan universal. Bagian ini hanya dapat menyampaikan inti dari konsep yang disampaikan. Berbeda dengan itu, particulars lebih bersifat spesifik dan konkret, di mana bagian itu akan membuat apa yang disampaikan menjadi "down to earth." Sikap, emosi, tindakan, dan pentingnya sebuah konsep Alkitab hanya dapat dibawa melalui particulars. Misalnya, "Allah menjawab doa" adalah sebuah pernyataan generals yang merupakan inti dari sebuah ide. Namun, sebuah cerita tentang suatu jawaban doa yang spesifik adalah particulars, di mana melaluinya pendengar dapat mengalami ide tersebut. ${ }^{41}$ Wayne McDill menjelaskan:

While generals are interpretations of reality, the particulars aim to have the hearer experience the principles of Scripture in his imagination. The generals set the concept forth in principle. The particulars drive it home in the understanding, imagination, reason, and volition of the hearer. They connect the concept to his experience, either remembered or imagined. Without this connection to experience, the principles are remote, irrelevant, not credible. ${ }^{42}$

Pemikiran manusia tidak dapat terus-menerus berkutat pada yang generals, tetapi membutuhkan yang particulars, yaitu yang "down to earth," spesifik, dan dari kebenaran menuju

\footnotetext{
${ }^{41}$ Wayne McDill, The 12 Essential Skills for Great Preaching (Nashville: Broadman and Holman, 1994), 224.

${ }^{42}$ Ibid.
}

pengalaman. Inilah yang menyebabkan mengapa perhatian para pendengar dibangkitkan kembali ketika pengkhotbah mulai membuat penggambaran atau menyampaikan cerita. Pada sisi yang lain, sepertinya ada kontrol otomatis dalam pikiran pendengar yang menghentikan perhatian ketika mereka menerima bagian generals yang berlebihan. ${ }^{43}$

Berkaitan dengan imajinasi, John Piper menjelaskan bahwa otak manusia tidak hanya melakukan pekerjaan mengamati, menganalisis, mengorganisasi, dan mengingat saja, tetapi juga membayangkan (berimajinasi). Artinya, otak kita mampu membayangkan sesuatu yang tidak terlihat, tetapi mungkin ada di suatu tempat dan menjelaskan apa yang ada di sana. Kemampuan yang luar biasa ini disebut Piper "the most God-like," artinya ada kemiripan dengan ketika Allah menciptakan alam semesta dari sesuatu yang tidak ada. ${ }^{44}$ Dengan demikian Allah sudah memberikan sebuah kemampuan kepada manusia untuk berpikir secara kreatif. Penggunaan daya tersebut akan membantu manusia memahami konsep-konsep yang abstrak dan menunjukkan penghargaan manusia terhadap karunia tersebut. Piper menyatakan, "The supremacy of God in the life of the mind is not honored when God and his amazing world are observed truly, analyzed duly, and communicated boringly." 45 Karena itu para pengkhotbah perlu memikirkan bagaimana menggunakan dan mengembangkan kemampuan istimewa yang dimiliki manusia ini. Piper menjelaskan:

When we speak of beautiful truth, we must think of a pattern of words, perhaps a poem. We must conceive something that has never existed before and does not now exist in any human mind. We must think of an analogy or metaphor or illustration which has no existence. The imagination must exert itself to see it in our mind, when it is not there. We must create word combinations and music

${ }^{43}$ Ibid., 225.

${ }^{44}$ John Piper, "God Is Not Boring," http://www.desiringgod.org/articles/god-is-not-boring (diakses pada 29 Oktober 2014).

${ }^{45}$ Ibid. 
that have never existed before. All of this we do, because we are like God and because he is infinitely worthy of ever-new words and songs. ${ }^{46}$

Penyampaian cerita merupakan sebuah metode yang kaya dengan imajinasi di mana sesuatu konsep yang abstrak dijelaskan dengan cara baru, rangkaian kata-kata dan kalimat baru, serta situasi yang lebih konkret. Ketika kita menggunakannya sebagai sarana dalam berkomunikasi untuk penyampaian kebenaran, maka hal ini akan menolong pendengar untuk memahami dengan baik dan dapat menarik perhatian mereka, karena "Imagination is the key to killing boredom." ${ }^{47}$

\section{Kesimpulan}

Ilustrasi yang berbentuk cerita dapat menjadi alat yang efektif dalam penyampaian sebuah kebenaran. Penggunaan ilustrasi yang berbentuk cerita menjadi unsur yang perlu ada dan dipikirkan dengan sungguh-sungguh dalam sebuah khotbah. Artinya, setiap pengkhotbah perlu memberikan waktu yang cukup untuk memilih dengan tepat ilustrasi yang berbentuk cerita, menempatkan ilustrasi tersebut pada bagian yang tepat dalam khotbahnya, dan melatih diri untuk menyampaikannya dengan baik.

\footnotetext{
${ }^{46}$ Ibid.

${ }^{47}$ Ibid.
} 


\section{Daftar Kepustakaan}

Bryson, Harold T. Expository Preaching: The Art of Preaching Through a Book of the Bible. Nashville: Broadman \& Holman, 1995.

Carter, Terry G., J. Scott Duval, dan J. Daniel Hays. Preaching God's Word. Grand Rapids: Zondervan, 2005.

Chapell, Bryan. Using Ilustrations to Preach with Power. Wheaton: Crossway, 2001.

Fasol, Al. Essentials for Biblical Preaching: An Introduction to Basic Sermon Preparation. Grand Rapids: Baker, 1989.

Hergenhahn, B.R. dan Matthew H. Olson, Theories of Learning. Jakarta: Prenada Media Group, 2008.

Kilinger, John. Dasar-dasar Khotbah. Jakarta: Gunung Mulia, 2011.

Koessler, John. "View from the Pew." Dalam The Art and Craft of Biblical Preaching, diedit oleh Haddon Robinson dan Craig Brian Larson, 124-126. Grand Rapids: Zondervan, 2005.

McDill, Wayne. The 12 Essential Skills for Great Preaching. Nashville: Broadman and Holman, 1994.

Nielsen, Glenn. "Preaching Doctrine in a Postmodern Age." Concordia 27/1 (Januari 2001) 17-29.

Piper, John. "God Is Not Boring." http://www.desiringgod.org/articles/god-is-not-boring.

Robinson, Haddon. Biblical Preaching. Grand Rapids: Baker, 1980.

Simmons, Annete. Whoever Tells The Best Story Wins: How to Use Your Own Stories to Communicate with Power and Impact. New York: American Management Association, 2007.

Spurgeon, Charles H. "Illustration in Preaching." Dalam The Company of Preachers, diedit oleh Richard Lischer, 316-323. Grand Rapids: Eerdmans, 2002.

Stott, John. Between Two Worlds: The Challenge of Preaching Today. Grand Rapids: Eerdmans, 1982.

Torgesen III, William. "Learning to Tell the Story." Dalam The Moody Handbook of Preaching, diedit oleh John Koessler, 267-278. Chicago: Moody, 2008. 